\title{
Testemunhos reveladores do cuidado como pertença mútua
}

Felipe Rocha ${ }^{1}$

O fascínio da narrativa edênica, aquela recebida da herança hebraica encontrada entre os capítulos primeiro e terceiro do livro bíblico do Gênesis e, geralmente conhecida como "história da Criação" ou "história de Adão e Eva", reside numa luminosidade semântica que habita sob a possibilidade de aproximação daquilo que podemos denominar como o problema existencial humano fundamental, que abarca a nossa contradição entre a pulsão de obter a vida a partir de nós mesmos, e o chamado divino para realizar um modelo de existência moldado por uma comunhão invariavelmente relacional e amorosa.

Nosso desastre, diria Yannaras (1991, p. 77), é esse impulso desenfreado e desesperado por sobrevivência que diante da finitude de nossa mortalidade como seres criados, nos ilusiona em torno do equívoco de que podemos viver "como uma unidade existencial que extrai sobrevivência de sua hipóstase, de seus próprios poderes e funções", e não de uma comunhão de amor. Em verdade, a nossa experiência humana é a constante possibilidade de nos alimentarmos apenas para nossa preservação, apenas para sobrevivência de uma individualidade que no desprezo do vínculo ontológico entre todos os seres e a Divindade alimenta-se de seu delírio atômico e de sua rejeição da vida trinitária.

"Os nossos sofrimentos do presente", para lembrar aqui São Paulo, constituem-se como consequências dessa desordem existencial e não de uma falha de cumprimento de uma obrigação moral. Em nossa ficção mônade, ou seja, na ideia ilusória que vivemos sem partes e de forma autônoma, multiplicam-se as distopias das nossas sociedades onde os contornos opressores e autoritários criam e recriam o que chamo de "violência caínica" em referência a história bíblica igualmente do Gêneses onde Caim não apenas mata seu irmão Abel, mas se isenta do cuidado e da responsabilidade para com ele. Esse modelo ou regime de violência surge exatamente como protótipo ou paradigma social estrutural moldado pela negação da corresponsabilidade fraterna (“Sou acaso guardião de meu irmão?") e que, a partir de nosso cafetino inconsciente colonial-capitalístico ${ }^{2}$, ganhou ares epidêmicos nas dimensões macropolíticas e micropolíticas da modernidade global (RONILK, 2018).

O chamado divino, porém, de realizar um modelo de existência baseado na comunhão de amor e liberdade relacionais, segue inflando o mundo pelo hálito do Espírito mesmo que respiremos o bafo do governante do império do ar e do príncipe dessa era que nos asfixia com

\footnotetext{
${ }^{1}$ É psicanalista e professor de estudos religiosos. É autor e coorganizador do livro A Mística do Bem Viver [Editora Senso]. Atualmente é pesquisador assistente associado ao Intervention Programme to improve patient journey and reduce Stigma via community Education - ECLIPSE (FASA/ISC/UFBA/SIM-HUPES/UFBA/Keele University). E-mail: feliperochasan@ufba.br

2 O "inconsciente colonial-capitalístico" é uma expressão chave para designar a fase cognitiva ou subjetiva do capitalismo como padrão não apenas econômico da colonialidade, mas subjetivo e inconsciente. O uso da expressão "cafetino" é uma referência a sua vibração e frequência sobre os nossos corpos que são prostituídos pelas relações do capital que de nossos corpos obtém os seus rendimentos.
} 
suas falsidades e lorotas necromantes [discursos mortíferos e de morte] que buscam naturalizar a impiedade, a morte e a injustiça (Efésios 2:2). Embora o estrangulamento desse sistema de coisas ameace as nossas vidas por sua orientação autodestrutiva, a nossa fé enquanto compromisso e fidelidade para com o modelo de existência da ekklēsía ${ }^{3}$ não é vã já que, como cidadãos e cidadãs da basileia ${ }^{4}$, formamos um "povo mantido em posse peculiar" que renunciou a todo poder cosmopolítico enganador e malicioso do "deus desse mundo" e dos "tronos, domínios e potestades" dos impérios e sua extravagante violência (1 Pedro 2:9; 1 João 5:19; Colossenses 1:16).

O que quero dizer é que, enquanto formamos uma nova humanidade em restauração que não reconhece lealdades rivais dada a sua fidelidade a basileia e a Cristo, todos os laços sociais e espirituais relacionados aos aspectos contingenciais de nossa experiência se tornam a massa para o fermento que somos (HART, 2009, p. 113-119). Assim, ao passo que "a expectativa da criação aguarda os sons de Deus", e rumamos para restauração e restituição universal/cósmica de todas as coisas (apokatastasis) anunciada por padres como Orígenes, Gregório de Nissa e Máximo, o Confessor, é o testemunho do cuidado como pertença mútua em meio ao mundo decadente que revela a verdadeira "definição da pessoalidade como ela aparece à luz da pessoalidade divina, como uma categoria relacional que difere da noção de indivíduo" e traduz a práxis trinitária para qual somos chamados e eroticamente atraídos (ZIZIOULAS, 2006, p. 176177).

Se o desafio sindêmico exige que frente à quarentena pensemos se estamos 'utilizando nosso tempo morto para nos libertarmos do imperativo do agir desenfreado e para pensarmos a respeito do sentido (ou da falta de sentido) da situação na qual nos encontramos' (ŽlŽEK, 2020, p. 22). Só posso concluir que urge fazer ecoar o modelo de existência da ekklēsía que, baseandose numa ontologia relacional, centraliza o sentido da sequência de nossas tragédias na rejeição da comunhão amorosa da pessoalidade divina, no impulso desenfreado pela sobrevivência individual e na negação da corresponsabilidade fraterna que hoje encontra-se institucionalizada nas organizações, subjetivada no inconsciente e democratizada pela moralidade burguesa.

Na perspectiva dos padres e madres, a renúncia da barbárie triunfalista do eu atômico que quer viver por si mesmo e através de suas próprias funções envolvia um exercício ascético que na transfiguração do que somos atua para que vivamos muito mais além dos "nossos desejos e necessidades impessoais". Sem a intenção de banalizar importantes conceito-chaves da teologia patrística, penso que se "ascetismo é a luta da pessoa contra a natureza rebelde que

\footnotetext{
${ }^{3}$ Comumente traduzida como "igreja" nas línguas moderno-ocidentais, é uma expressão grega que referia-se a assembleia formada pelos cidadãos nas cidades-estados democráticos da Antiga Grécia. O uso dessa expressão pelos primeiros cristãos/as indica como os mesmos se imaginavam: membros/as de uma companhia de relacionamentos para uma luta comum na polis (cidade) e não de mais uma religião nascente.

${ }^{4}$ Basileia é uma expressão oriunda da língua grega que é comumente traduzida por "reino" e surge na Bíblia Sagrada como "Reino de Deus". Compreendo, porém, que a palavra "reino" e a expressão "reino de Deus" prejudicam o sentido de basileia ou de malkuta (seu correlato em aramaico, língua usada por Jesus de Nazaré). Preservo, portanto, a expressão grega basileia como significando o poder governante e a glória incriada de Deus que nos conduz uma comunidade aliançada a liberdade de toda forma de servidão.
} 
busca realizar por si mesma", e que "põe dinamicamente em ação sua vontade pessoal para restaurar sua natureza à comunhão com a graça da vida" dentro de uma comunhão baseada em relações pessoais e relacionamento - pertença mútua -, pode-se dizer que o cuidado exercitado durante a quarentena, pode converter-se em uma prática ascética. Sendo necessário que transcenda nossa divagação rotineira por autopreservação individual cega, e transmute cada ato abnegado de si e de seus interesses - diversão, aglomeração, sexo, etc - em formas de cuidado do dom da vida do outro e da comunidade (YANNARAS, 1984, p. 112).

Os testemunhos de pertencimento mútuo brotaram de todos os cantos e lugares e podem ser lidos e celebrados de tantas formas distintas como, por exemplo, na persistência de uma juventude que traduziu seu vigor em medidas de cuidados para com aqueles cujos cabelos brancos Ihe fizeram mais vulneráveis ao adoecer. Na profusão de religiosas/os e leigos/as, bem como tantas outras pessoas na sociedade civil, que de forma voluntária dispuseram tempo e recursos para assistir aos mais pequenos como, por exemplo, a população de rua, muitas vezes arriscando seus próprios corpos para que o menor de seus irmãos e irmãs não padecesse de fome, frio ou uma palavra de sabedoria e encorajamento.

Muitos entre nós foram estimulados a refletir nos significados do que é viver com comorbidades, e como os doentes precisam de cuidados especiais e atenção relevante como requer a prática cristã que sempre advogou por esses. Por outro lado, fomos expostos a tantos e tantos itinerários terapêuticos que revelaram-nos como as cidades precisam caminhar para estruturas cada vez mais sólidas de cuidados em saúde. Além disso, descobrimos como a dimensão do processo de saúde-doença-cuidado deve impulsionar uma teologia pública engajada em construir o bem comum envolvida em temas sanitários e epidemiológicos da saúde coletiva e de suas relações entre igreja e sociedade, especialmente quando os interesses econômicos de corporações religiosas que prostituem a figura de Cristo ameaçam o sistema de saúde de um país.

Mas, caminhando um pouco mais adiante nessa escrita poderíamos ainda pensar nas expressões de pertencimento mútuo e de cuidado que se encarnam na forma de movimentos de cooperação relacional que aspiram uma linguagem profética, e que seguiram brotando no contexto sindêmico, cooperativo, a partir de uma solidariedade fraternal. Entendo por linguagem profética ou linguagem da profecia a semântica da "compreensão da marcha da história e as obrigações históricas associadas a cada momento", ou seja, aquilo que permite avaliar a 'encarnação e irrupção crítica e radical da Verdade em períodos reais da vida histórica' (YANNARAS, 1983, p. 53-56).

Ao interpretarmos o chamado da humanidade como realização de um modelo de existência relacional à imagem e semelhança de Deus, ou seja, no modelo trinitário, a queda é a expressão do fracasso existencial de responder ao chamado. Dessa forma, pensamos a realidade como marcada ancestralmente por aquele fracasso existencial em viver o modelo de existência trinitário. A profecia é obra da manifestação da Verdade que busca 'transfigurar o 
fracasso humano na medida da revelação da autenticidade da existência humana'. Na teologia cristã, a Verdade não é um conjunto de ideias ou pressupostos teóricos, mas uma pessoa, a saber, Jesus Cristo. Logo, preservar e andar na/com a Verdade é um modelo de relacionamento e não uma confissão. Encarnar a Verdade, portanto, é antes de tudo, viver este relacionamento.

Nesse ínterim, ela não é apenas crítica "no sentido de que simplesmente contradiria outros pontos de vista", porque invariavelmente busca "comparar a plenitude da comunhão pessoal trinitária com nossa realidade social'.

Dito isso, entendo como movimentos de cooperação relacional que aspiram uma linguagem profética, como confluências do hálito ou sopro do Espírito que bailam sobre a autoridade do asfixiante império do ar que rouba a aspiração e inspiração. Assim, lançado fora o medo pelo amor encorajam-se para encarnar e irromper no período real de cada momento histórico comparando o chamado original divino com a realidade vivida.

A ekklēsía, como nomenclatura, marca a "identidade das primeiras comunidades cristãs", significando "uma coletividade de pessoas que querem viver juntas na luta para alcançar a existência verdadeira, para tornar a existência realidade, como seu objetivo comum". Sendo assim, não é demais dizer que nossos corpos que renascem como corpos eclesiais pela água e pelo Espírito, acabam por buscar manifestar na polis, na cidade, "um modo específico de relações de união, um modo de existência e coexistência" orientada pela "luta comum, pela luta objetivada em alcançar a vida de acordo com a verdade" (YANNARAS, 2013, p. 21-22).

É impulso, portanto, movido pelo Espírito, que nossos corpos eclesiais projetem a partir do pertencimento mútuo, superar os regimes de decadência e morte porque alimentam-se eucaristicamente ou numa celebração de ação de graças onde assim como o pão e o vinho são recebidos como alimentos básicos de sustentação da vida, a liberdade de relação, a comunhão e o amor são os requisitos básicos de uma existência não baseada na autopreservação, mas no relacionamento e na pertença que manifestam a mesa fraterna. Logo, não é apenas natural como pretendido que, fermentando a massa, estejamos estimulados para encarnar criativamente a linguagem profética em regime de cooperação relacional com outras pessoas das mais distintas matizes e matrizes. Riquezas que se movem para transformar a cidade, a fim de que ela não seja apenas um assentamento de sujeitos que buscam seus próprios interesses.

Creio, então, que experiências como a do Movimento de Juventudes e Espiritualidades Libertadoras, que nasceu dos Encontros Nacionais de Juventudes e Espiritualidade Libertadora traduzem em seus próprios contornos poéticos e em sua própria estética, percebida pelos diferentes rostos e belezas que encarna, esse impulso para a comunhão. Um impulso orientado para congregar e reunir de forma cooperativa os relevos das distintas juventudes, que encontram nas suas tradições religiosas e espirituais uma autenticidade renovadora, que pode ir traçando esse esforço comparativo entre o chamado divino e a realidade vivida. Mas não apenas isso, pois busca encarnar a Verdade como antecipação escatológica daquela libertação gloriosa dos 
filhos e filhas de Deus e de suas minorias abraâmicas ${ }^{5}$ naquele movimento da basileia que "é" e "não é", que "já chegou", mas que "está próxima".

Em minha participação durante a pandemia no Grupo de Formação do MEL - como carinhosamente é chamado, na dinâmica da colaboração amiga contribuí para construir dois materiais temáticos envolvendo diferentes linguagens como texto, música, poesia e imagem. Foi um desdobramento de irrupções interiores e de exercícios associativos que fortaleceram meu compromisso com ekklēsía e com polis, especialmente quando dedicamos uma edição à reflexão sobre o cuidado e espiritualidade daqueles que estão em constante movimento. Por fim, porém, não menos importante, há de se relatar com alegria o encontro organizado sob o título "Militância, Mística e Cuidado", durante a primavera passada, bem como os "Círculos do Cuidado" que ocorrem regularmente nesse regaço acolhedor.

Em contextos de emergência global agravada pela pandemia e enfeitiçada cruelmente pelo inconsciente colonial-capitalístico decadente, tais medidas de cooperação relacional que se fazem e existem ao lado de tantas outras, são formas de pertencimento mútuo valioso que reúne o vigor da juventude e a sabedoria dos cabelos grisalhos no encontro intergeracional na escola da sapiência profética. Sim, diante das tantas provas de nosso fracasso em realizar individualmente, por nós mesmos, a verdadeira vida a partir de nossos delírios atômicos, podemos ir exercitando a amplitude da potencialidade transformadora que pela relacionalidade e testemunho profético resiste a violência caínica contra a fraternidade.

\section{Questões para reflexão:}

1. O autor nos fala que "o chamado divino de realizar um modelo de existência baseado na comunhão de amor e liberdade relacionais, segue inflando o mundo pelo hálito do Espírito". Traga sinais de que esta experiência está presente nas comunidades, vizinhanças, amigos ou familiares. 2. A experiência da pandemia do COVID 19 vem servindo para nos libertarmos do imperativo do agir desenfreado e pensarmos a respeito do sentido do viver e do bem viver?

3. Comente o conceito de ekklēsía e relacione com uma prática de comunidade religiosa ou não religiosa - "uma coletividade de pessoas que querem viver juntas na luta para alcançar a existência verdadeira, para tornar a existência realidade, como seu objetivo comum"

\section{REFERÊNCIAS BIBLIOGRÁFICAS}

HART, David Bentley. Atheist delusions : the Christian revolution and its fashionable enemies. London: Yale University Press, 2009.

RONILK, Suely. Esferas da insurreição: Notas para uma vida não cafetinada. São Paulo, n-1 edições, 2018

\footnotetext{
${ }^{5}$ Aqui essa é uma referência a todos e todas aqueles/as que estando em relacionamentos concretos e amigos no meio da multidão de povos aspiram a esperança de uma "nova terra" tal como Abraão, o personagem bíblico que foi chamado de "amigo de Deus". Essa "nova terra" para onde caminhamos ou que projetamos é pautada em relações de amor, paz, justiça e equidade.
} 
ŽlŽEK, Slavoj. Pandemia: Covid-19 e a reinvenção do comunismo. São Paulo: Boitempo, 2020. ZIZIOULAS, John. Communion and Otherness: Further Studies in Personhood and the Church. London: T\&T Clark, 2006.

YANNARAS, Christos. Against religion: the alienation of the ecclesial event. Massachusetts: Holy Cross Orthodox Press, 2013.

Elements of Faith: An Introduction to Orthodox Theology. London: T\&T Clark, 1991. The Freedom of Morality. New York: St Vladimir's Seminary Press, 1984. A Note on Political Theology. St. Vladimir's Theological Quarterly, 27 (1), p. 53-56, 1983. 